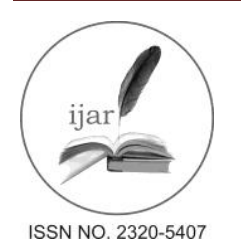

Journal homepage: http://www.journalijar.com

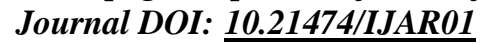

INTERNATIONAL JOURNAL

OF ADVANCED RESEARCH

RESEARCH ARTICLE

\title{
IMPACT OF INDUSTRIAL EFFLUENTS ON THE DIVERSITY AND POPULATION STRUCTURE OF ROTIFER FAUNA IN RIVER BASANTAR, JAMMU (J\&K, INDIA).
}

\author{
K. K. Sharma and "Minakshi Saini \\ Department of Zoology, University of Jammu, Jammu-180006, J\&K, India.
}

\section{Manuscript Info}

Manuscript History:

Received: 18 March 2016

Final Accepted: 29 April 2016

Published Online: May 2016

Key words:

Pollution, Diversity, Rotifer,

Temporal variations, Spatial

variations.

*Corresponding Author

Minakshi Saini

\begin{abstract}
An attempt has been made to study the impact of industrial pollution on the species diversity and distribution of rotifer fauna in river Basantar in the Jammu province of Jammu \& Kashmir during the period from December, 2009 to November, 2011. A total of 16 rotifer taxa belonging to 12 Genera and 10 Families were recorded. Among all the ten families, Family Brachionidae was dominant. The temporal variations in rotifer population exhibited winter and spring maxima at all the stations while spatial variations revealed a rise in their density from least polluted to highly polluted sites mainly affected with industrial effluents. The rotifer taxa Brachionus sps., Philodina, Keratella sp., Lecane luna, Lecane (M.) bulla and Filinia longiseta had their highest density at the polluted stations of the river and were identified as pollution indicator taxa. Diversity, richness and evenness was highest at least polluted sites while dominance at highly polluted sites.
\end{abstract}

\section{Introduction:-}

Rivers and streams are a valuable freshwater resource, irreplaceable, priceless assets providing important habitats and corridors for nature conservation, recreation, amenity and economic growth (Bellos et al., 2004). At a given river station, water quality depends on many factors, including: (i) the proportion of surface run-off and groundwater, (ii) reactions within the river system governed by internal processes, (iii) the mixing of water from tributaries of different quality (in the case of heterogeneous river basins), and (iv) inputs of pollutants (Meybeck et al., 1992). The anthropogenic impact on aquatic ecosystems has become a crucial topic of concern (Bellos et al., 2004) as most rivers have been modified by human activities like rapid industrialization, extensive urbanization, intensive agriculture practices and burning of fossil fuel (Wetzel, 2001; Dale et al., 2005; Grimm et al., 2000) to the extent of alteration in the water quality and structure and function of aquatic biota (Stoddard et al., 2006) and ultimately leading to the degradation of riverine ecosystem (Schleiger, 2000).

Aquatic organisms are good biological indicators of water pollution in a river and the ecological health of an aquatic ecosystem can be analyzed through biological indicators on the basis of their presence or absence, relative abundance, community structure and function (Karr et al., 1986; Landres et al., 1988).

Zooplanktons are minute heterotrophic aquatic organisms that are non-motile or are very weak swimmers and are present at various depths in their own niches in every type of aquatic environment (Majagi and Vijaykumar, 2009). The freshwater zooplankton comprises Protozoa, Rotifers, Cladocerans, Copepods and Ostracods. Rotifera (Rotatoria or wheel animalcules) is a group of small, usually microscopic animals that constitute an important component of freshwater ecosystems. They are ubiquitous, occurring in almost all types of fresh water habitats, from large permanent lakes to small temporary puddles and as well as flowing water environments, such as rivers or streams. They play a crucial role in the aquatic food chains due to their qualitative and quantitative occurrence 
which is affected by the complex interaction of various physico-chemical, geographical, biological and ecological parameters (Orstan, 1999; Hendrik, 2007; Hulyal and Kaliwal, 2008). Rotifer diversity and distribution is mainly influenced by deteriorating quality of water in freshwater ecosystems (Devetter and Sed'a, 2003). Their importance in maintaining the ecological balance and their ability to colonize diversified aquatic and semi-aquatic biotopes by building up substantial densities within short time-intervals make them ideal for ecological considerations as well as potential bio-indicators to assess the status of an aquatic system with respect to the pollution load (Stemberger, 1979; Sladecek, 1983; Ekhande et al., 2013).

River 'Basantar' (the present study site) is a tributary of river Ravi and is an important water body of Jammu and Kashmir State of India. It flows through district Samba of Jammu region and is one of the main sources of drinking water for its inhabitants (Fig 1a). The establishment of an Industrial Growth Centre with large number of industrial units along the side of this river causes direct discharge of the industrial waste into the river through drainage thereby severely deteriorating the water quality of the river and thus drastically affected the overall ecology of river Basantar.

In order to assess the impact of pollution load on the species composition and population structure of rotifer fauna of river Basantar, a study was carried out for a period of two years i.e. from December, 2009 to November, 2011 at four pre-designated stations of river Basantar viz. St I, II, III and IV (Fig 1b). St I lie near the National Highway Bridge and is under continuous stress of anthropogenic influences in the form of cattle-bathing, washing of vehicles, fishing, drawing of water using electric motor and mining of sand. St II is about $2.2 \mathrm{~km}$ downstream from the Station I near Railway Bridge. It receives industrial effluents from the industrial drainage. St III lies $1 \mathrm{~km}$ downstream from Station II. Sand mining, cattle-bathing and drawing of water using electric motor (by Gujjar community residing at the bank of the river) are the common activities at this station. St IV is about $3.5 \mathrm{~km}$ downstream from Station III.

Thus, the current study describes the impact of industrial pollution on the species composition and distribution of rotifer fauna of river Basantar so as to yield guiding principles for devising strategies regarding the monitoring and conservation of river Basantar.

\section{Material and Methods:-}

Sampling:- Plankton (Rotifers and phytoplankton) were collected from all the stations on a monthly basis by

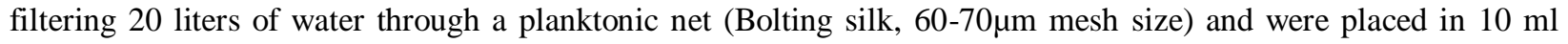
plastic vials to which $5 \%$ formalin was added for preservation.

Qualitative Analysis:- Preserved samples of rotifers and phytoplankton were scanned under compound microscope in the laboratory and were further identified following Ward and Whipple (1959), Jyoti and Sehgal (1980), Adoni (1985), Pennak (1989), Battish (1992) and Edmondson (1992).

Quantitative Analysis:- The numerical count of rotifers and phytoplankton was done by adopting Sedwick-Rafter Cell method and Drop count method respectively (Adoni, 1985). The preserved samples were centrifuged and concentrated to $5 \mathrm{ml}$. In Sedwick-Rafter Cell method which is better suited for zooplankton, a coverslip was diagonally placed over the S-R cell and $1 \mathrm{ml}$ of the concentrate was transferred into the cell with the help of a large broad dropper. The S-R cell cavity was covered by rotating the coverslip slowly. Rotifers were counted in six transects. The number of Rotifers per litre were calculated following Ind. $I^{-1}=\mathrm{n}(\mathrm{V} / \mathrm{v}) \times 1 / \mathrm{c} \times 10^{3}$, in which ' $\mathrm{n}$ ' is total number of individuals in observed transects, ' $V$ ' is volume of the sample in counting cell $\left(\mathrm{mm}^{3}\right)$, ' $\mathrm{v}$ ' is the volume of observed transects $\left(\mathrm{mm}^{3}\right)$ and ' $\mathrm{c}$ ' is the concentration factor (original volume of sample in $\mathrm{ml} /$ volume of sample concentrate in $\mathrm{ml}$ ). In Drop count method, the number of phytoplankton per litre were calculated following Ind. $1^{-1}=\mathrm{A} \times 1 / \mathrm{L} \mathrm{x} \mathrm{n} / \mathrm{v}$, where ' $\mathrm{A}$ ' is the number of organisms per drop, ' $\mathrm{v}$ ' is the volume of one drop (ml), ' $\mathrm{n}$ ' is the total volume of the concentrated sample $(\mathrm{ml})$ and ' $\mathrm{L}$ ' is the volume of original sample (l).

Physico-chemical Parameters:- Some important physico-chemical parameters of water were determined at the sampling sites. The water temperature was recorded by a mercury bulb thermometer, Depth by a meter rod, Transparency by secchi disc and Water Flow/Water Velocity by flowmeter. Dissolved oxygen of the water was estimated by sodium azide modification of Winkler's method (A.P.H.A., 1985). 
Statistical Methods:- Standard Deviation (sd) was calculated using the formula: SD $=\sqrt{ } \sum \mathrm{d}^{2} / \mathrm{n}$, where $\mathrm{d}$ is the deviation from the mean $\left(x-x^{-}\right)$and $n$ is the total number of observations. Species diversity was determined by applying Shannon-Weaver Diversity Index (Shannon and Weaver, 1949), $\mathrm{H}^{\prime}=-\sum_{\mathrm{i}=1}^{\mathrm{s}} \mathrm{p}_{\mathrm{i}} \ln \left(\mathrm{p}_{\mathrm{i}}\right)$, in which $\mathrm{H}^{\prime}$ is the information content of sample (bits/individuals), $\mathrm{S}$ is the number of species and $\mathrm{p}_{\mathrm{i}}$ is the proportion of total species belonging to ${ }_{i}^{\text {th }}$ species. Simpson's Index of dominance (C) was calculated according to Stone and Pence (1978), C = $\sum_{\mathrm{i}=1}^{\mathrm{s}} \mathrm{p}_{\mathrm{i}}{ }^{2}$, where $\mathrm{p}_{\mathrm{i}}$ is the proportion of total number of individuals of each species. Species richness was determined applying Marglef's Index (Marglef, 1968), $\mathrm{d}^{\prime}=\mathrm{S}-1 / \mathrm{Ln}(\mathrm{N})$, in which $\mathrm{S}$ is the total number of species, $\mathrm{N}$ is the total number of individuals in sample and $\mathrm{Ln}$ is the Natural log. Evenness was calculated using the Pielou's Index, $\mathrm{E}=$ $\mathrm{H}^{\prime} / \mathrm{ln} \mathrm{S}$ (Pielou, 1969), where $\mathrm{H}^{\prime}$ is the Index of diversity of Shannon-Weaver, ln is the Natural $\log$ and $\mathrm{S}$ is the total number of species.

Percentage similarity of the rotifers in different seasons was calculated by Sorenson's Quotient of Similarity (Sorenson, 1948), $Q / S=2 j / a+b(100)$, where $\mathrm{j}$ is the number of species common to both samples, a is the total number of species in sample 1 and $b$ is the total number of species in sample 2. Morisita-Horn Index (Wolda, 1983) was applied to determine the similarity of rotifer communities in different seasons in terms of abundance using the formula: $\mathrm{MH}=2 \sum_{\mathrm{i}=1}^{\mathrm{n}}\left(\mathrm{N}_{\mathrm{ia}} \mathrm{N}_{\mathrm{ib}}\right) /\left(\mathrm{d}_{\mathrm{a}}+\mathrm{d}_{\mathrm{b}}\right) \mathrm{N}_{\mathrm{a}} \mathrm{N}_{\mathrm{b}}$, in which $\mathrm{N}_{\mathrm{ia}} \& \mathrm{~N}_{\mathrm{ib}}$ number of individuals of species ' $\mathrm{i}$ ' in the samples for site $\mathrm{a}$ and $\mathrm{b}, \mathrm{N}_{\mathrm{a}} \& \mathrm{~N}_{\mathrm{b}}$ are the number of individuals in the samples from sites $\mathrm{a}$ and $\mathrm{b}$ and $\mathrm{n}$ is the total number of species. Two-way ANOVA was calculated with the help of SPSS Software (Ver. 16.0) to determine whether there is a significant temporal variation in the different characteristics of rotifer community among different seasons/months as well as stations.

\section{Results:-}

A list of 16 rotifer taxa belonging to 12 Genera and 10 Families along with their density encountered at four different stations of river Basantar during the study period (December, 2009 to November, 2011) is presented in Table 1. Of all the species, 5 species belonged to Family Brachionidae while Family Lecanidae and Philodinidae were represented by 2 species each; whereas Family Asplanchnidae, Testudinellidae, Mytilinidae, Euchlanidae, Filinidae, Trichotridae and Notommatidae were constituted of single species each.

Comparative analysis of rotifer fauna of river Basantar as depicted in Table 1 revealed its highest density and mean annual abundance at St II \& III (the heavily polluted sites) as compared to the St I \& IV (the least polluted sites). The rotifer density increased from St I to St III and then gradually declined at St IV during both the years of study period. The rotifer population exhibited winter and spring maxima at all the stations and a gradual decline was recorded in the density of rotifers with the progression of summer season (Fig 2). Seasonal variation in the rotifer density at different stations during the first year varied from 0-40.3 ind. $\mathrm{I}^{-1}$ at St I, 0-234.6 ind. $\mathrm{I}^{-1}$ at St II, 0-290.5

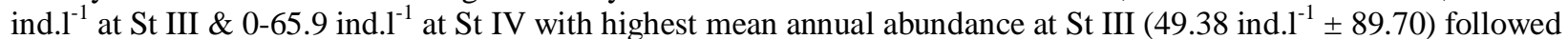
by St II (48.53 ind. $\left.1^{-1} \pm 83.20\right)$, St IV (12.02 ind. $\left.1^{-1} \pm 18.84\right)$ and St I $\left(6.08\right.$ ind. $\left.1^{-1} \pm 10.46\right)$. During the second year of study, the rotifers at St I, II, III and IV ranged from 0.5-21.3 ind. $.^{-1}, 5.5-57.7$ ind. $^{-1}, 3.6-27.9$ ind. $^{-1}$ and 1-16.8 ind..$^{-1}$ with mean annual abundance of 6.36 ind. $1^{-1} \pm 6.64,20.78$ ind. $.^{-1} \pm 14.60,12.80$ ind. $.^{-1} \pm 6.57$ and 4.78 ind. $.^{-1} \pm 4.63$ respectively.

During the first year of present study, Brachionus sps. had highest annual average density at St II (21.00 ind. $.^{-1} \pm$ 59.53) which started declining at St III (16.48 ind. $\left.1^{-1} \pm 47.59\right)$ and St IV (2.98 ind. $\left..^{-1} \pm 7.62\right)$ (Fig $3 \mathrm{a}$ a-b). The least annual average abundance was noticed at St I $\left(0.41\right.$ ind. $\left.1^{-1} \pm 0.95\right)$. Similarly, during the second year, it showed highest annual average abundance of 4.83 ind. $1^{-1} \pm 4.75$ at St III followed by 2.83 ind. $.^{-1} \pm 2.99$ at St II, 1.28 ind. $1^{-1} \pm$ 1.73 at St IV and 0.70 ind. $1^{-1} \pm 1.17$ at St I. Further, annual average abundance of another rotifer taxa Philodina sp. during both the years was found higher at St II (16.03 ind. $.^{-1} \pm 46.96$ and 6.23 ind. $\left..^{-1} \pm 10.88\right)$ and St III (24.90 ind. $\mathrm{l}^{-1}$ \pm 68.14 and 2.70 ind. $1^{-1} \pm 5.05$ ) respectively whereas the least annual average abundance of this taxa was observed at St I \& IV (Fig 3 c-d). Other rotifer taxa that recorded their presence at the polluted stations of river Basantar were Keratella sp., Lecane luna, Lecane (M.) bulla and Filinia longiseta. On the other hand, Asplanchna sp., Testudinella sp. and Cephalodella sp. exhibited their complete absence at these sites (Table 1).

The physico-chemical parameters of four pre-designated stations of river Basantar are presented in Fig 4. Statistical analysis of rotifer fauna revealed that the diversity, richness and evenness were highest at the least polluted sites while dominance was highest at the polluted sites during the study period (Table 2). Sorenson's Quotient of similarity (Q/S i.e. comparison between stations by using qualitative presence-absence Type) exhibited that St II and 
III were found more similar during both the years. Morisita-Horn Index based on meristic data i.e. counts of individuals referring quantitative indices, showed maximum values of similarity between St III and IV in the first year \& St II \& III in the second year (Table 3). Two-way ANOVA recorded significant temporal variations in rotifer density among different stations $\left(\mathrm{F}_{3,69}=5.028\right.$, $\left.\mathrm{p}<0.05\right)$ as well as among months $\left(\mathrm{F}_{23,69}=5.335, \mathrm{p}<0.05\right)$.

\section{Discussion:-}

In river Basantar, the dominance of Family Brachionidae with respect to the number of species inhabiting the river is considered as a typical characteristic of tropical environment (Dumont, 1983, Bekleyen, 2003; Geng et al., 2005). Peaks in the density of rotifer fauna of river Basantar observed in winter and spring season was in line with the results of Annalakshmi and Amsath (2012) and Sharma et al. (2013) who also observed winter and spring maxima of rotifers in the waterbodies they studied. Sharma et al. (2010) and Khalifa and Sabae (2012) also recorded high rotifer abundance in spring season. Edmondson (1965) and Baker (1979) associated the higher abundance of rotifers in winter with the favourable temperature and availability of abundant food in the form of bacteria, nanoplankton and suspended detritus. Dominance of rotifers in winters has also been reported by Kulshreshtra and Joshi (1999). Dhembare (2011) linked the rotifer abundance with the low water level which supported the present observation of higher abundance during the period when the water level was lower as depicted in Fig 4c-d. Moreover, Purushothama et al. (2011) declared temperature, turbidity, transparency and DO as important factors controlling density of rotifers while Chetelat and Pick (2006) and Sulehria and Malik (2012) related richness of rotifer density and diversity with three features viz. stagnant water, better light penetration and high concentration of phytoplankton (an important source of food for the zooplankton). During the present study, winter and spring season were characterized by slow water flow, higher transparency resulting into enhanced penetration of light, and greater abundance of phytoplankton as depicted in Fig 4\&5; and thus had maximum density of rotifers. Sulehria and Malik (2012) also suggested that slow water flow provided better environment for rotifers to reproduce. Differences in the seasonal density of rotifers at all the stations may be associated with the nutrition and biotic interactions as also suggested by Pawar and Pulle (2005) and Annalakshmi and Amsath (2012).

Among different stations, the higher abundance of rotifers at highly polluted sites (St II \& III) was associated with the lower concentration of DO as compared to less polluted sites (St I \& IV). This observation got support from the findings of Arora (1966), Prabhavathy and Sreenivasan (1977) and Purushothama et al. (2011) who stated DO as controlling factor for the density of rotifers. Moreover, Venkateswarlu and Jayanti (1968), Mishra and Saksena (1998), Shinde et al. (2011), Spoljar et al. (2011) and Verma et al. (2013) confirmed the presence of comparatively higher rotifer population at the sites receiving waste which is in consonance with present findings. Rotifers are more sensitive to environmental changes and used as indicators of water quality (Gannon and Stemberger, 1978; Ferdous and Muktadir, 2009); and are commonly abundant in eutrophic freshwater ecosystems (George, 1966; Herzig, 1987). Arora (1965), Eloranta (1980) and Sladecek (1983) reported the abundance of rotifers in polluted waters and suggested that they are tolerant to various sorts of pollution.

Higher annual average abundance of rotifer taxa Brachionus \& Philodina at St II \& III of river Basantar indicated the pollution indicator nature of these taxa which got support from the results of Angeli (1976), Margalef (1983), Orcutt and Pace (1984), Mishra and Saksena (1998), Mageed (2008), Dirican et al. (2009), Bhagat et al. (2010), Ahamed et al. (2011), Mola (2011), Meshram (2012) and Kolhe et al. (2013) who stated that the dominance of rotifer taxa such as Brachionus is indicative of eutrophic condition of the water body while Arora (1965), Sladecek (1983), Palharya and Malviya (1988) considered Philodina as pollution indicator taxa.

The presence of other rotifer taxa like Keratella sp., Lecane luna, Lecane (M.) bulla, Filinia longiseta at polluted stations of river Basantar clearly indicated them as pollution tolerant. Unni (1996), Mishra and Saksena (1998) and Javed (1999 \& 2006) stated that Keratella and Filinia were high pollution tolerant species. However, complete absence of Asplanchna sp., Testudinella sp. and Cephalodella sp. at polluted sites clearly indicated that these species were sensitive towards pollution tolerance. Mishra and Saksena (1998) and Javed (2006) in their studies on different water bodies considered Cephalodella and Asplanchna as sensitive to pollution load that is in line with the present results.

According to Ogbeibu and Edutie (2002), sensitive species normally disappear as the water becomes polluted while tolerant ones survive the pollution stress and readily recovers downstream of the point of discharge. Similar pattern was also observed in the present study when pollution sensitive rotifer species disappeared at polluted stations while their density recovered downstream of the sites receiving industrial effluents. 
Gerritsen et al. (1998) stated that value of $\mathrm{H}^{\prime}$ increases with the number and distribution of species (biotic diversity) within the community and it was inversely related to the dominance of the community (Simpson, 1949 and Green, 1993) which is in consonance with the present observations. Walting et al. (1979) and Suresh et al. (2009) well opined that whenever the dominance index of zooplankton species was higher, the evenness index was lower and vice-versa, thereby supporting the present findings.
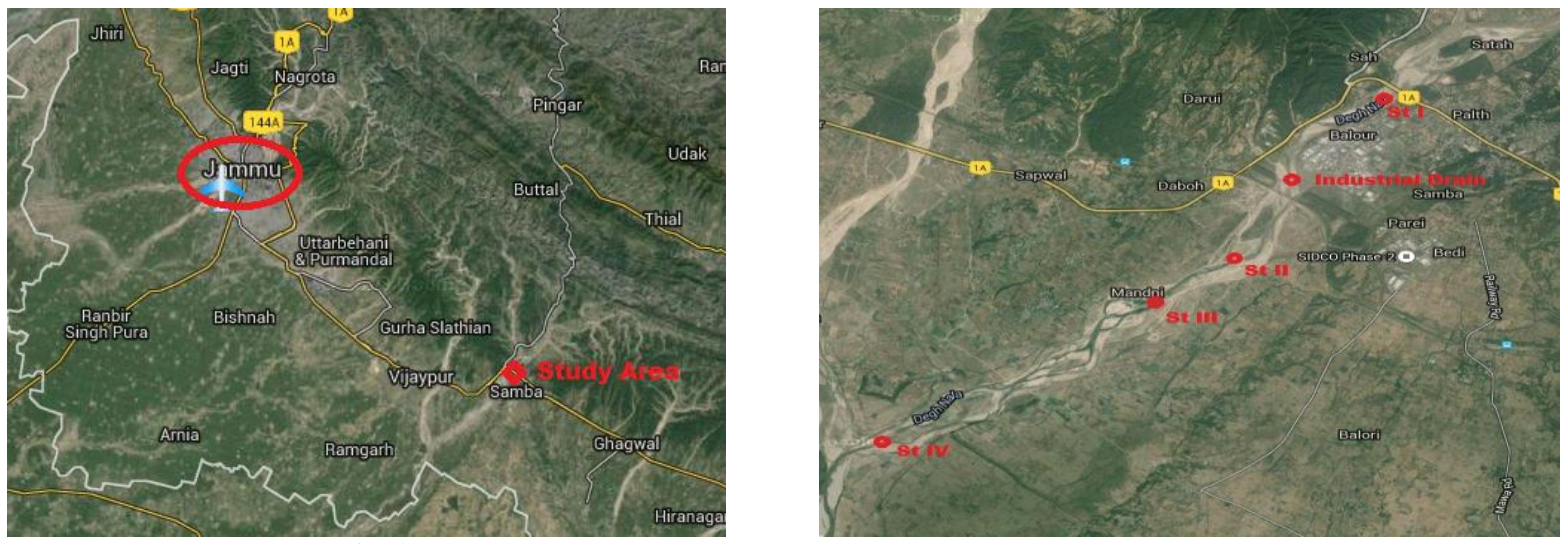

Fig 1:- Satellite view of river Basantar-the study area (from Google).
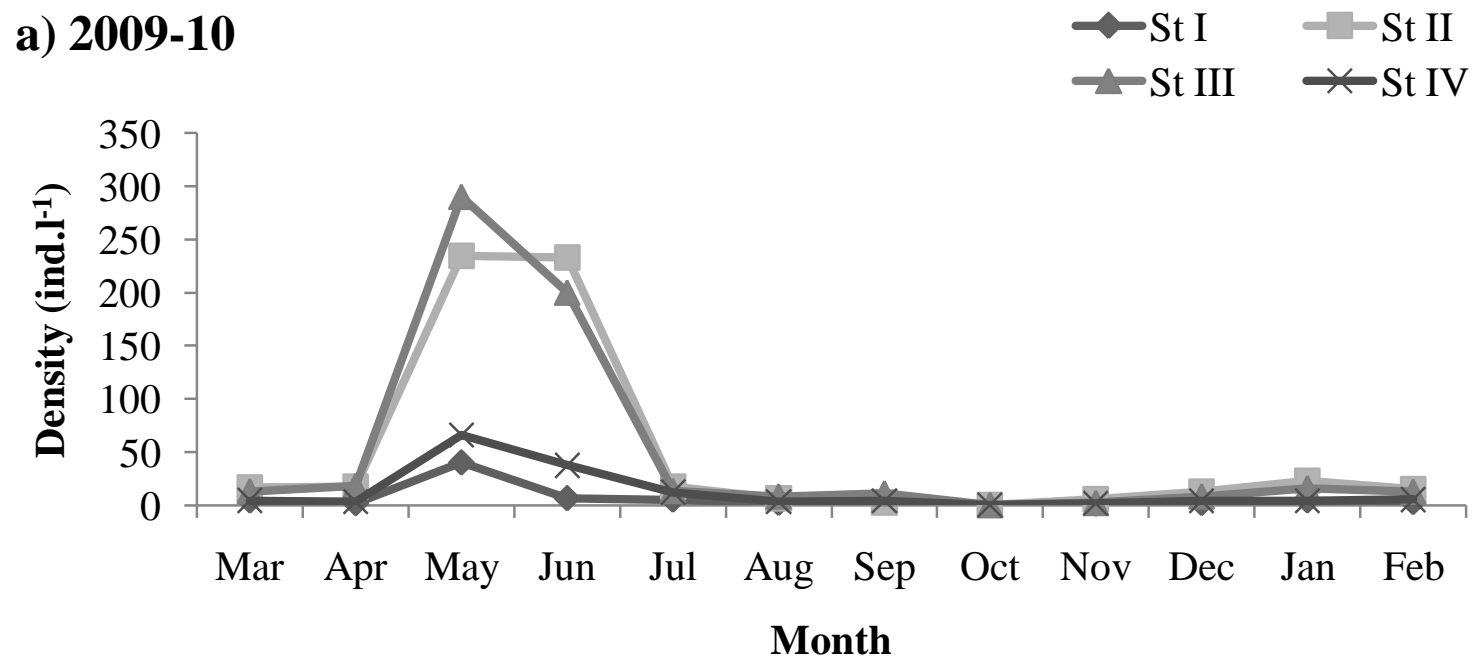

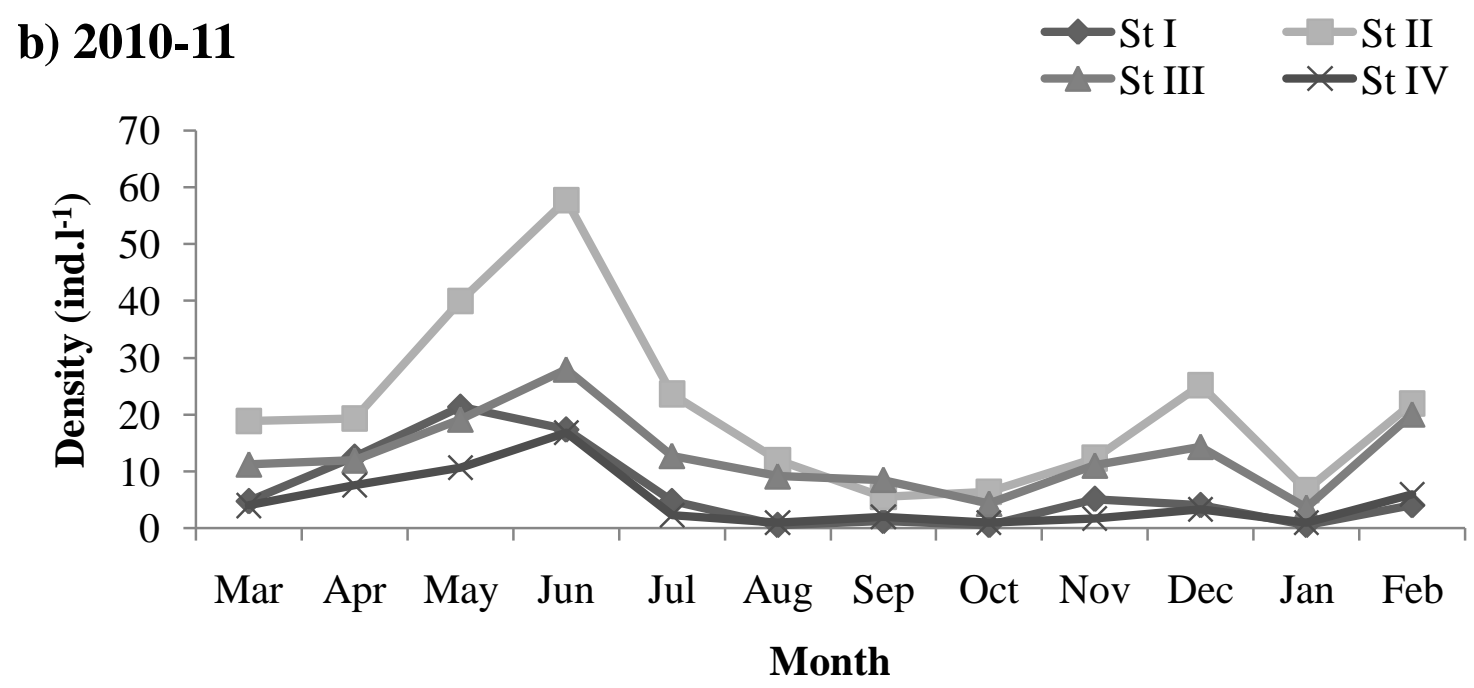

Fig 2:- Seasonal abundance (ind. $1^{-1}$ ) of rotifers at all the stations of river Basantar.

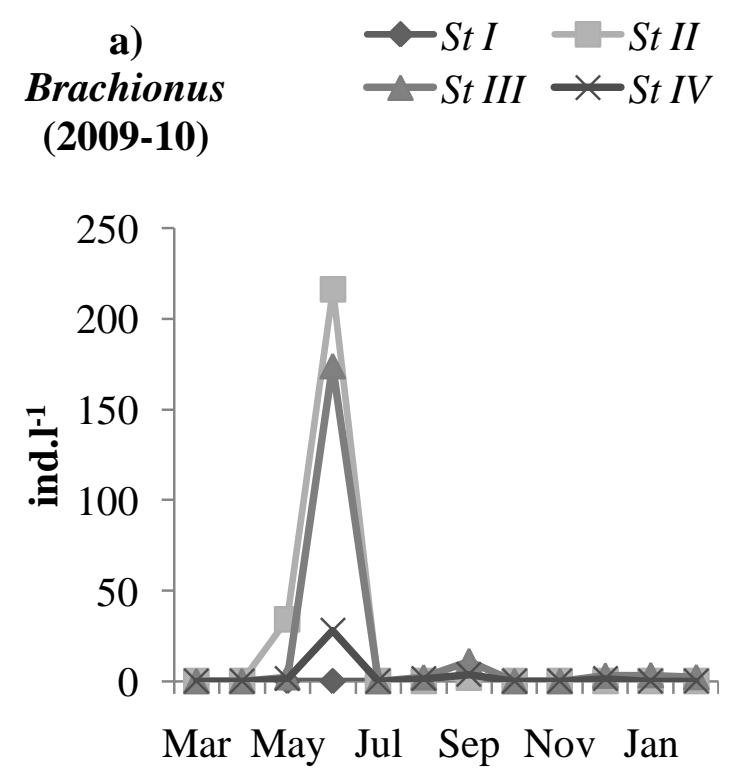

Month
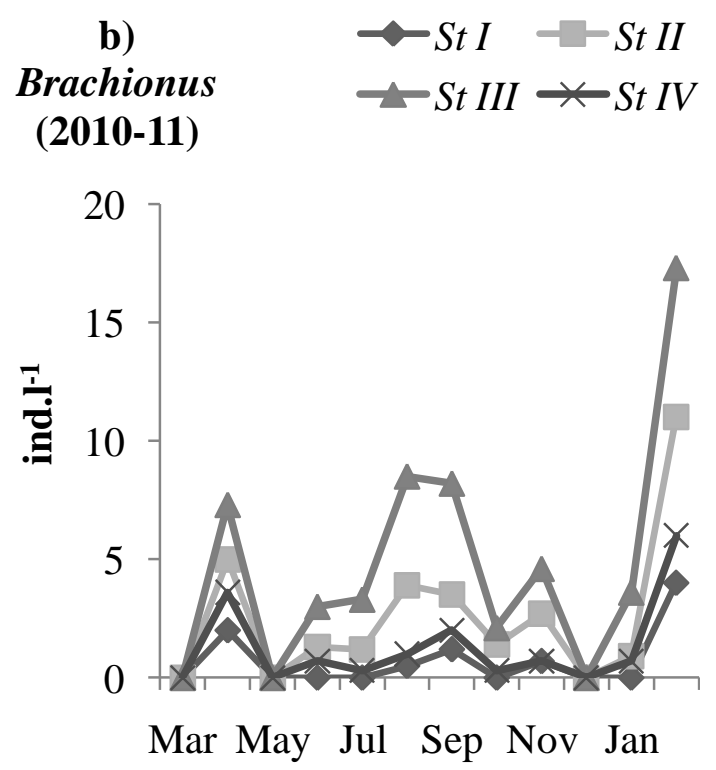

Month 

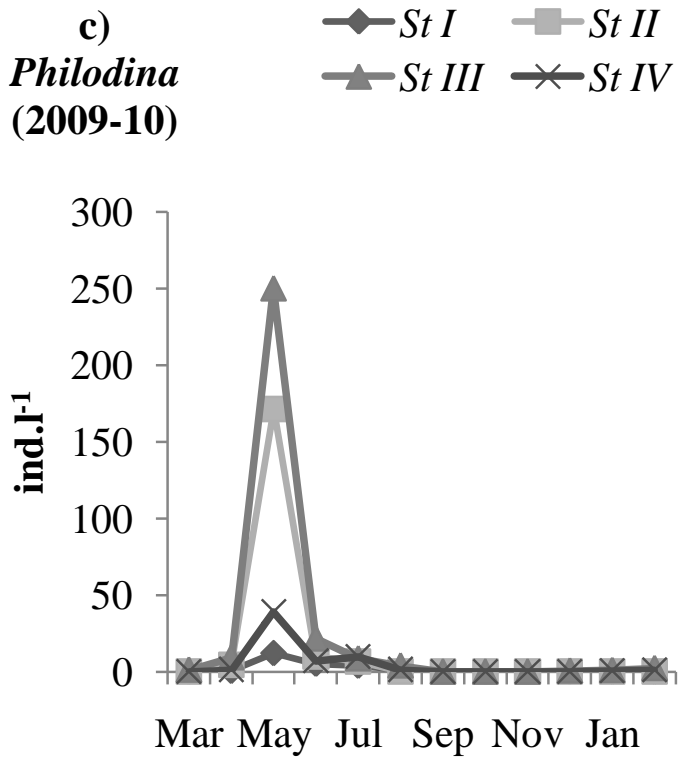

Month
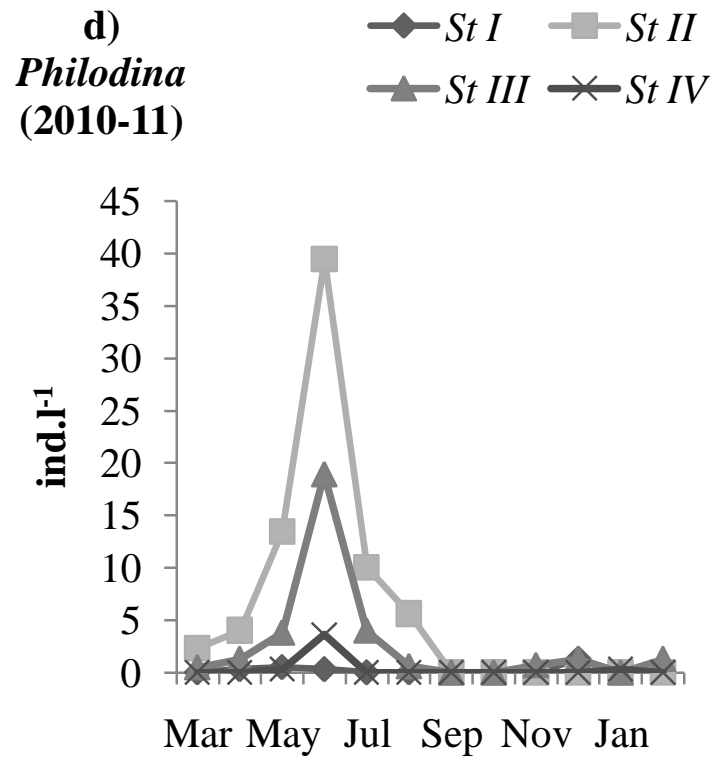

Month

Fig 3:-Seasonal abundance (ind. $\left.1^{-1}\right)$ of predominant rotifer taxa (Brachionus and Philodina) at all the stations of river Basantar.

a)

Water Temperature

(2009-10)
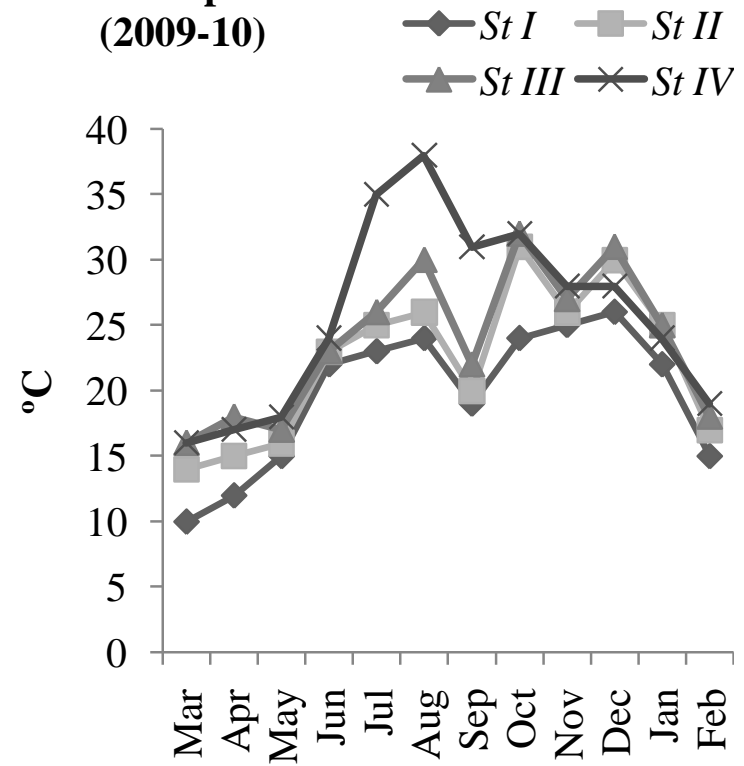

Month b)

Water Temperature

(2010-11) $\multimap S t I-S t I I$

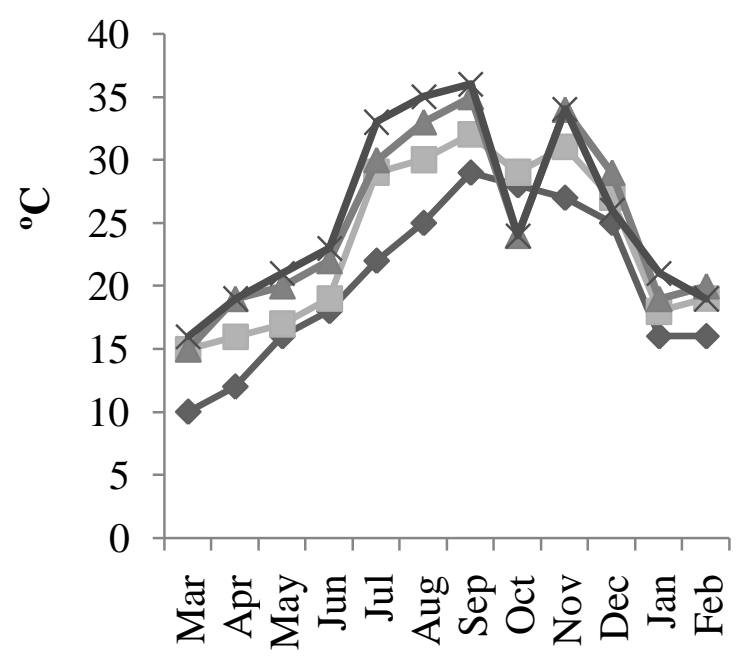

Month 
c)
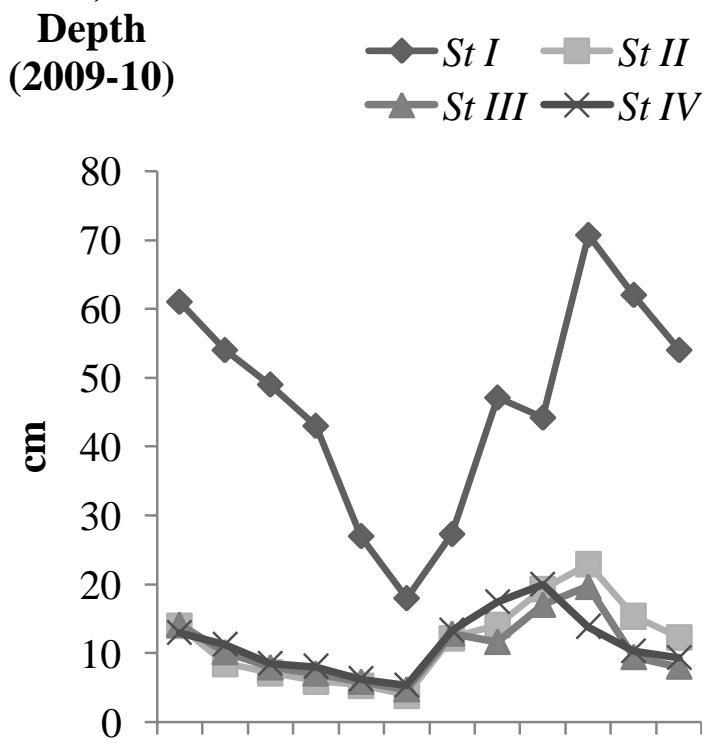

Mar May Jul Sep Nov Jan

Month

e)
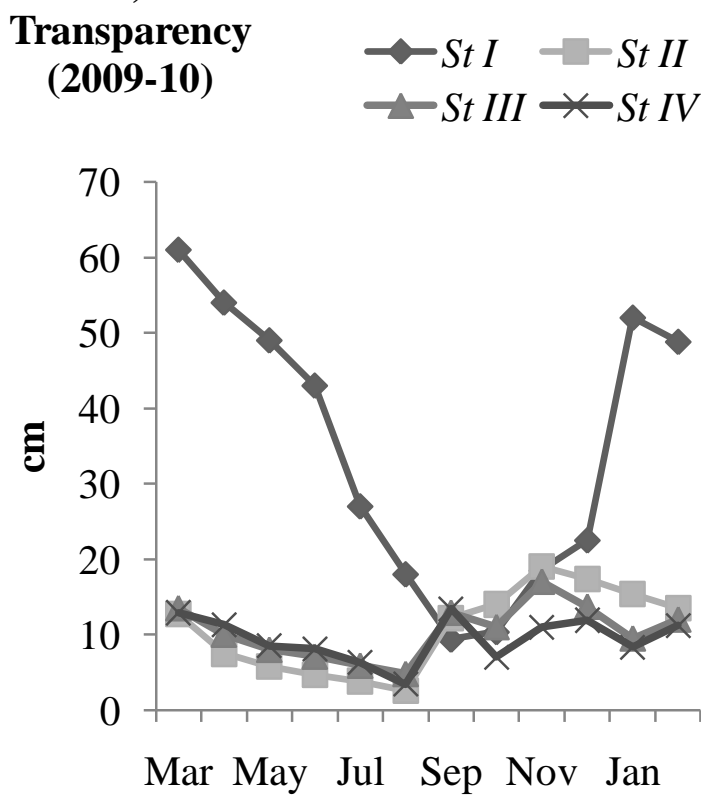

Month d)
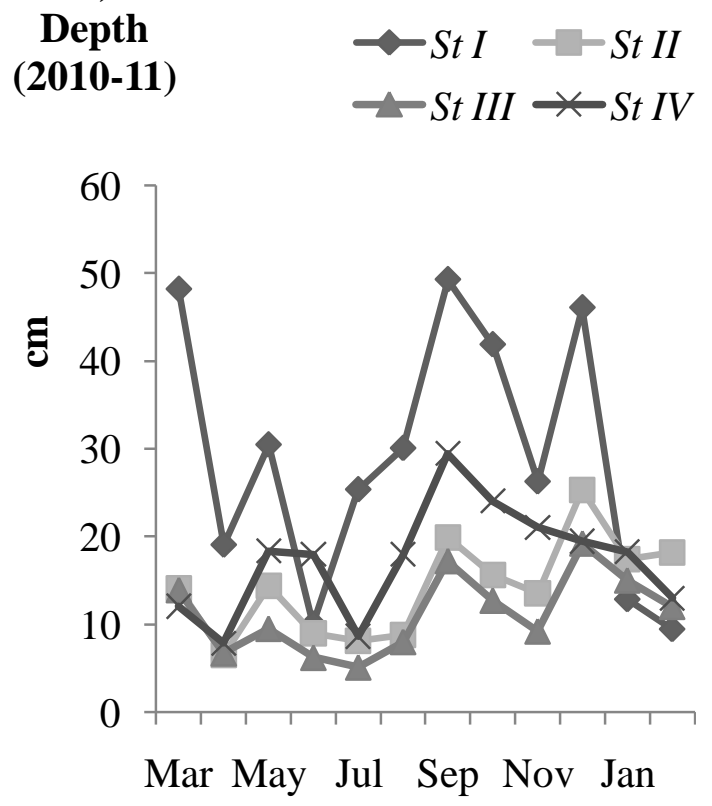

Month

f)
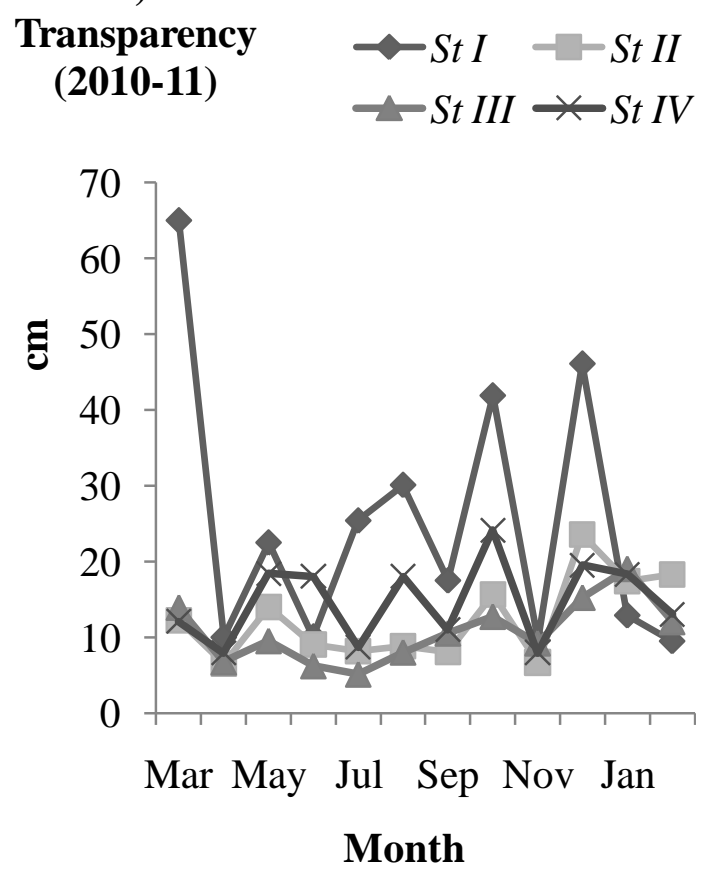
g)
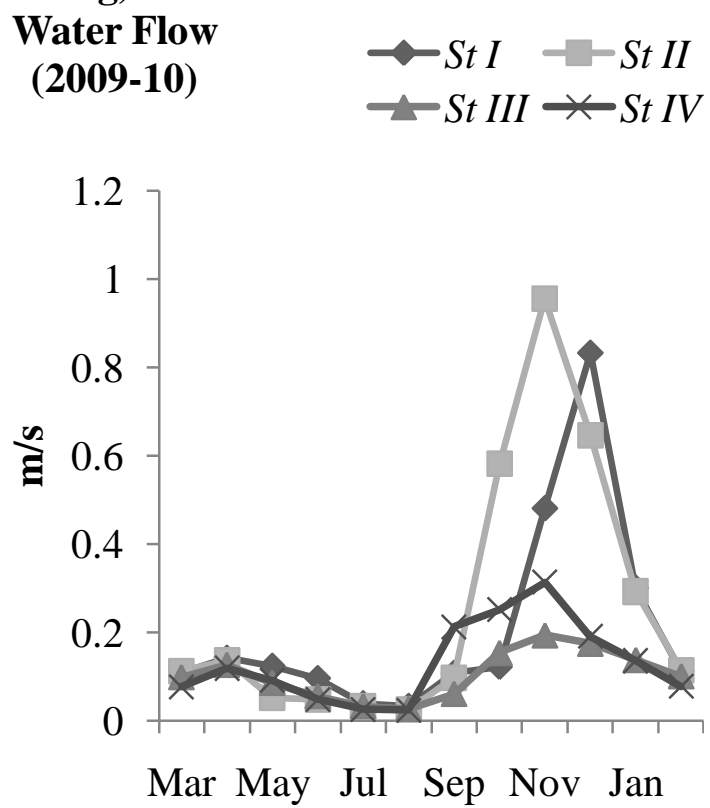

Month

i)
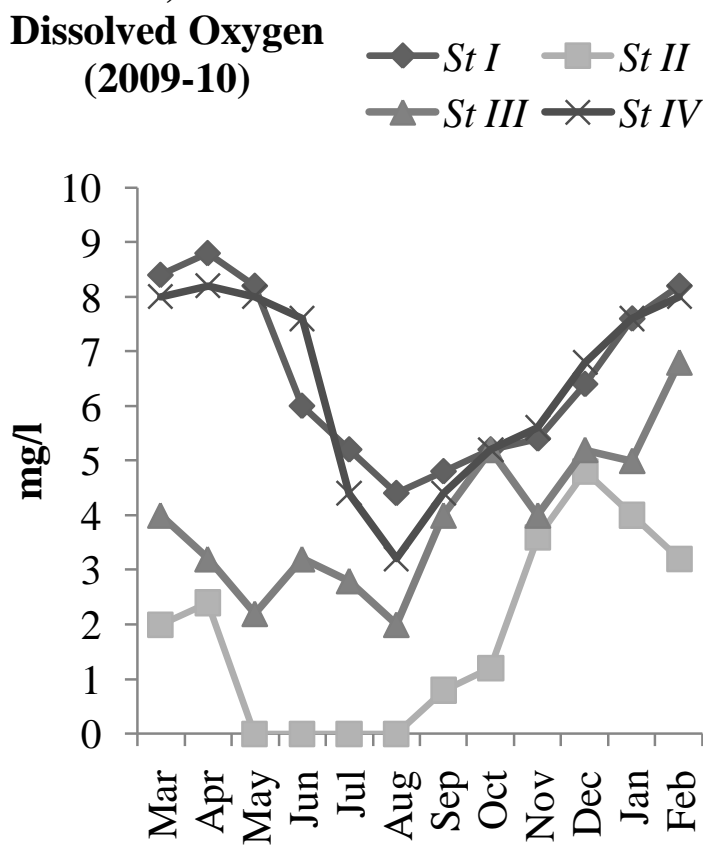

Month h)
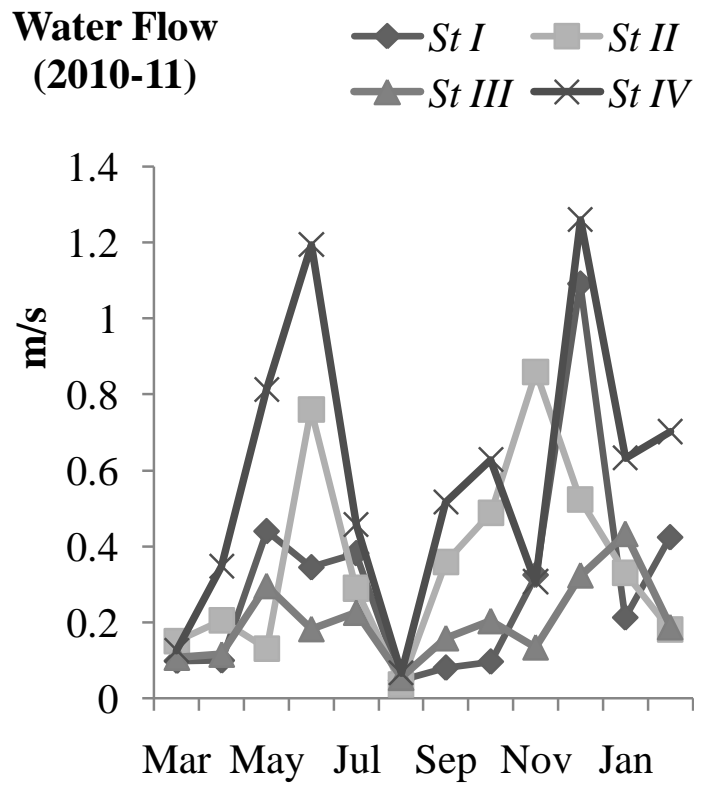

Month

j)
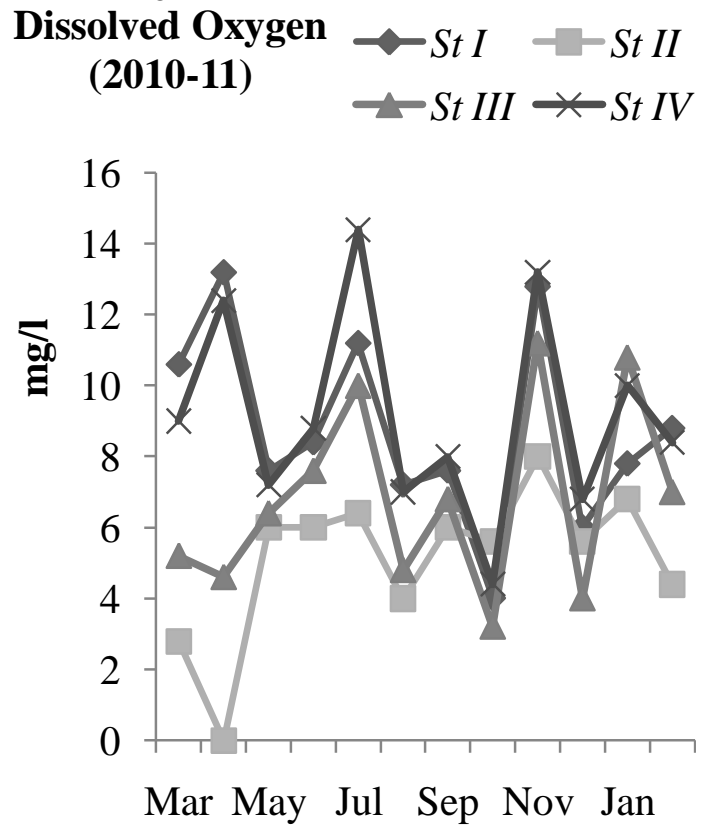

Month

Fig 4. Seasonal variations in physico-chemical parameters at all the stations of river Basantar. 
a)
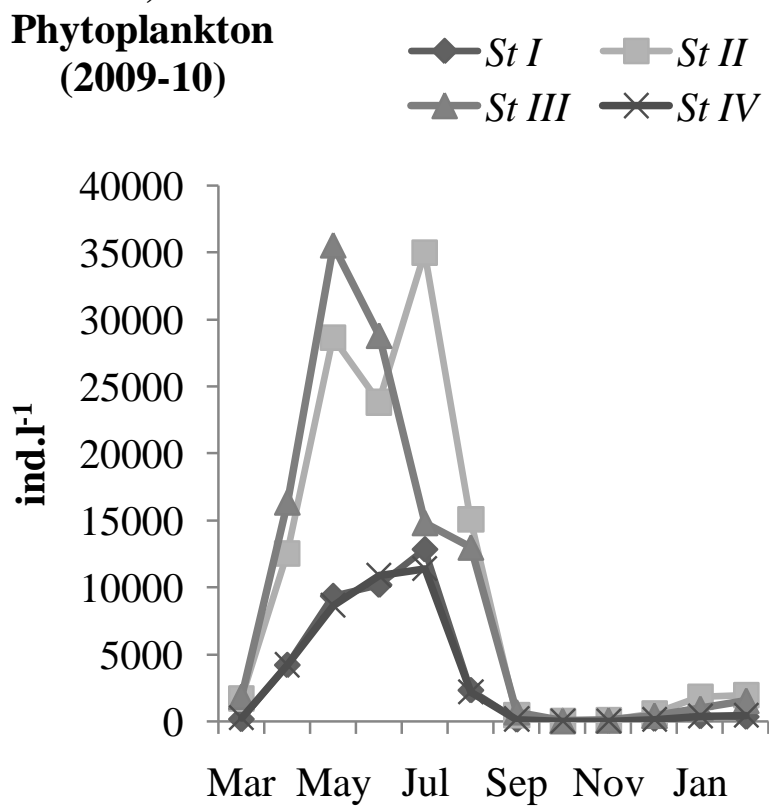

Month b)
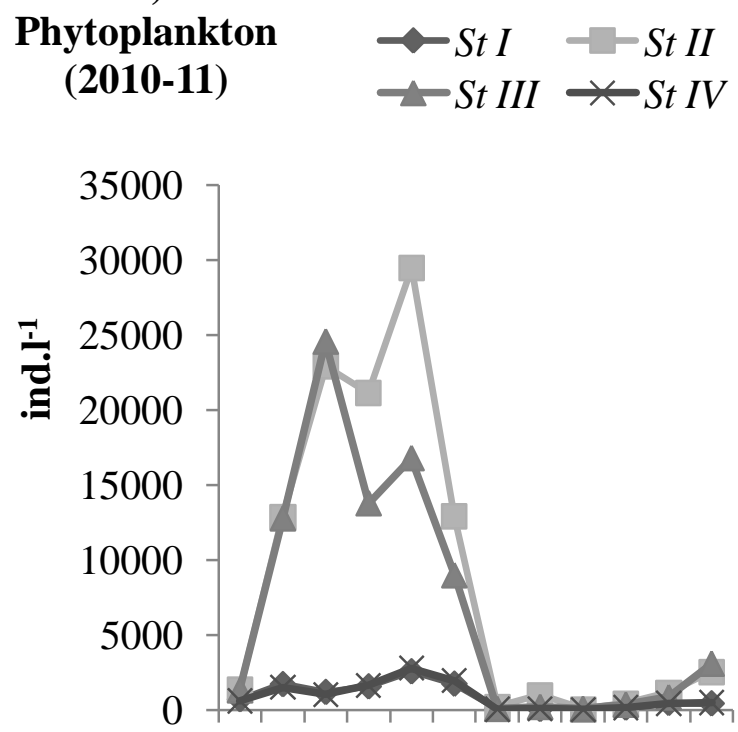

Mar May Jul Sep Nov Jan

Month

Fig 5:- Seasonal abundance (ind. $1^{-1}$ ) of phytoplankton at all the stations of river Basantar.

Table 1:- Density of rotifer community (ind. $1^{-1} \pm \mathrm{sd}$ ) in the sampling stations. In parentheses is the mean annual abundance value.

\begin{tabular}{|c|c|c|c|c|c|}
\hline Rotifer Taxa & Year & St I & St II & St III & St IV \\
\hline \multicolumn{6}{|l|}{ Brachionidae } \\
\hline \multirow[t]{2}{*}{$\begin{array}{l}\text { Brachionus } \\
\text { angularis }\end{array}$} & $2009-10$ & - & $\begin{array}{c}2.0 \\
(0.17 \pm 0.37)\end{array}$ & $\begin{array}{c}10.9 \\
(0.91 \pm 1.24)\end{array}$ & $\begin{array}{c}3.3 \\
(0.28 \pm 0.63)\end{array}$ \\
\hline & 2010-11 & $\begin{array}{c}4.0 \\
(0.33 \pm 0.75) \\
\end{array}$ & $\begin{array}{c}14.1 \\
(1.18 \pm 2.06) \\
\end{array}$ & $\begin{array}{c}25.4 \\
(2.12 \pm 3.26) \\
\end{array}$ & $\begin{array}{c}8.1 \\
(0.68 \pm 1.17) \\
\end{array}$ \\
\hline \multirow[t]{2}{*}{$\begin{array}{l}\text { Brachionus } \\
\text { calyciflorus }\end{array}$} & $2009-10$ & $\begin{array}{c}1.6 \\
(0.13 \pm 0.32)\end{array}$ & $\begin{array}{c}249.0 \\
(20.75 \pm 59.31)\end{array}$ & $\begin{array}{c}172.0 \\
(14.33 \pm 46.94)\end{array}$ & $\begin{array}{c}26.0 \\
(2.17 \pm 7.19)\end{array}$ \\
\hline & 2010-11 & $\begin{array}{c}3.9 \\
(0.33 \pm 0.57)\end{array}$ & $\begin{array}{c}12.9 \\
(1.08 \pm 1.42)\end{array}$ & $\begin{array}{c}25.3 \\
(2.11 \pm 2.48) \\
\end{array}$ & $\begin{array}{c}6.0 \\
(0.50 \pm 0.90)\end{array}$ \\
\hline \multirow[t]{2}{*}{$\begin{array}{l}\text { Brachionus } \\
\text { bidentata }\end{array}$} & $2009-10$ & $\begin{array}{c}0.6 \\
(0.05 \pm 0.17) \\
\end{array}$ & - & $\begin{array}{c}4.3 \\
(0.36 \pm 1.19) \\
\end{array}$ & $\begin{array}{c}1.3 \\
(0.11 \pm 0.36) \\
\end{array}$ \\
\hline & 2010-11 & $\begin{array}{c}0.5 \\
(0.04 \pm 0.14) \\
\end{array}$ & $\begin{array}{c}3.9 \\
(0.33 \pm 0.77)\end{array}$ & $\begin{array}{c}7.2 \\
(0.60 \pm 1.43) \\
\end{array}$ & $\begin{array}{c}1.2 \\
(0.10 \pm 0.23)\end{array}$ \\
\hline \multirow[t]{2}{*}{$\begin{array}{l}\text { Brachionus } \\
\text { quadridentatus }\end{array}$} & $2009-10$ & $\begin{array}{c}2.7 \\
(0.23 \pm 0.48) \\
\end{array}$ & $\begin{array}{c}1.0 \\
(0.08 \pm 0.28)\end{array}$ & $\begin{array}{c}10.6 \\
(0.88 \pm 1.69) \\
\end{array}$ & $\begin{array}{c}5.1 \\
(0.43 \pm 0.79)\end{array}$ \\
\hline & 2010-11 & - & - & - & - \\
\hline \multirow[t]{2}{*}{ Keratella sp. } & $2009-10$ & - & $\begin{array}{c}5.6 \\
(0.47 \pm 1.55) \\
\end{array}$ & $\begin{array}{c}1.3 \\
(0.11 \pm 0.36) \\
\end{array}$ & - \\
\hline & 2010-11 & - & - & - & - \\
\hline \multicolumn{6}{|l|}{ Asplanchnidae } \\
\hline \multirow[t]{2}{*}{ Asplanchna sp. } & $2009-10$ & $\begin{array}{c}1.5 \\
(0.13 \pm 0.28) \\
\end{array}$ & - & - & $\begin{array}{c}0.3 \\
(0.03 \pm 0.08) \\
\end{array}$ \\
\hline & 2010-11 & $\begin{array}{c}1.5 \\
(0.13 \pm 0.23) \\
\end{array}$ & - & - & $\begin{array}{c}0.8 \\
(0.07 \pm 0.15) \\
\end{array}$ \\
\hline
\end{tabular}




\begin{tabular}{|c|c|c|c|c|c|}
\hline \multirow[t]{2}{*}{ Testudinella sp. } & $2009-10$ & - & - & - & - \\
\hline & $2010-11$ & $\begin{array}{c}0.7 \\
(0.06 \pm 0.19)\end{array}$ & - & - & - \\
\hline \multicolumn{6}{|l|}{ Lecanidae } \\
\hline \multirow[t]{2}{*}{ Lecane luna } & $2009-10$ & - & $\begin{array}{c}30.8 \\
(2.57 \pm 3.03) \\
\end{array}$ & $\begin{array}{c}7.9 \\
(0.66 \pm 1.53) \\
\end{array}$ & $\begin{array}{c}2.7 \\
(0.23 \pm 0.57) \\
\end{array}$ \\
\hline & $2010-11$ & - & $\begin{array}{c}58.1 \\
(4.84 \pm 3.52) \\
\end{array}$ & $\begin{array}{c}18.4 \\
(1.53 \pm 1.85)\end{array}$ & $\begin{array}{c}4.9 \\
(0.41 \pm 0.77) \\
\end{array}$ \\
\hline \multirow[t]{2}{*}{ Lecane (M.) bulla } & $2009-10$ & $\begin{array}{c}14.2 \\
(1.18 \pm 1.29)\end{array}$ & $\begin{array}{c}92.5 \\
(7.71 \pm 6.11)\end{array}$ & $\begin{array}{c}40.5 \\
(3.38 \pm 3.03) \\
\end{array}$ & $\begin{array}{c}22.0 \\
(1.83 \pm 1.79) \\
\end{array}$ \\
\hline & 2010-11 & $\begin{array}{c}7.0 \\
(0.58 \pm 0.86)\end{array}$ & $\begin{array}{c}80.7 \\
(6.73 \pm 5.31)\end{array}$ & $\begin{array}{c}32.6 \\
(2.72 \pm 3.23)\end{array}$ & $\begin{array}{c}9.4 \\
(0.78 \pm 1.07)\end{array}$ \\
\hline \multicolumn{6}{|l|}{ Mytilinidae } \\
\hline \multirow[t]{2}{*}{ Mytilina ventralis } & $2009-10$ & $\begin{array}{c}0.6 \\
(0.05 \pm 0.17)\end{array}$ & $\begin{array}{c}0.5 \\
(0.04 \pm 0.14) \\
\end{array}$ & $\begin{array}{c}3.0 \\
(0.25 \pm 0.83) \\
\end{array}$ & - \\
\hline & $2010-11$ & $\begin{array}{c}1.7 \\
(0.14 \pm 0.28) \\
\end{array}$ & $\begin{array}{c}0.3 \\
(0.03 \pm 0.08) \\
\end{array}$ & $\begin{array}{c}1.3 \\
(0.11 \pm 0.36) \\
\end{array}$ & - \\
\hline \multicolumn{6}{|l|}{ Euchlanidae } \\
\hline \multirow[t]{2}{*}{ Euchlanis dilatata } & $2009-10$ & $\begin{array}{c}16.4 \\
(1.37 \pm 3.26)\end{array}$ & $\begin{array}{c}1.0 \\
(0.08 \pm 0.28) \\
\end{array}$ & $\begin{array}{c}40.9 \\
(3.41 \pm 6.75) \\
\end{array}$ & $\begin{array}{c}23.3 \\
(1.94 \pm 4.90) \\
\end{array}$ \\
\hline & $2010-11$ & $\begin{array}{c}24.4 \\
(2.03 \pm 2.81)\end{array}$ & $\begin{array}{c}2.0 \\
(0.17 \pm 0.39) \\
\end{array}$ & $\begin{array}{c}5.3 \\
(0.44 \pm 0.91) \\
\end{array}$ & $\begin{array}{c}11.4 \\
(0.95 \pm 1.57)\end{array}$ \\
\hline \multicolumn{6}{|l|}{ Philodinidae } \\
\hline \multirow[t]{2}{*}{ Philodina sp. } & $2009-10$ & $\begin{array}{c}22 \\
(1.83 \pm 3.46)\end{array}$ & $\begin{array}{c}192.3 \\
(16.03 \pm 46.96)\end{array}$ & $\begin{array}{c}298.8 \\
(24.90 \pm 68.14)\end{array}$ & $\begin{array}{c}59.6 \\
(4.97 \pm 10.69) \\
\end{array}$ \\
\hline & $2010-11$ & $\begin{array}{c}2.4 \\
(0.20 \pm 0.37)\end{array}$ & $\begin{array}{c}74.7 \\
(6.23 \pm 10.88)\end{array}$ & $\begin{array}{c}32.6 \\
(2.70 \pm 5.05)\end{array}$ & $\begin{array}{c}4.2 \\
(0.35 \pm 0.99)\end{array}$ \\
\hline \multirow[t]{2}{*}{ Rotaria rototaria } & $2009-10$ & - & - & $\begin{array}{c}1.0 \\
(0.08 \pm 0.28) \\
\end{array}$ & $\begin{array}{c}0.3 \\
(0.03 \pm 0.08) \\
\end{array}$ \\
\hline & 2010-11 & - & - & $\begin{array}{c}1.2 \\
(0.10 \pm 0.33)\end{array}$ & - \\
\hline \multicolumn{6}{|l|}{ Filinidae } \\
\hline \multirow[t]{2}{*}{ Filinia longiseta } & $2009-10$ & - & $\begin{array}{c}7.3 \\
(0.61 \pm 1.00) \\
\end{array}$ & $\begin{array}{c}1.3 \\
(0.11 \pm 0.19) \\
\end{array}$ & - \\
\hline & $2010-11$ & - & $\begin{array}{c}1.8 \\
(0.15 \pm 0.27)\end{array}$ & $\begin{array}{c}0.8 \\
(0.07 \pm 0.15) \\
\end{array}$ & - \\
\hline \multicolumn{6}{|l|}{ Trichotridae } \\
\hline \multirow[t]{2}{*}{ Trichotria sp. } & $2009-10$ & $\begin{array}{c}10.3 \\
(0.86 \pm 2.46)\end{array}$ & $\begin{array}{c}0.3 \\
(0.03 \pm 0.08) \\
\end{array}$ & - & $\begin{array}{c}0.3 \\
(0.03 \pm 0.08) \\
\end{array}$ \\
\hline & $2010-11$ & $\begin{array}{c}27.6 \\
(2.30 \pm 3.44)\end{array}$ & $\begin{array}{c}0.9 \\
(0.08 \pm 0.18)\end{array}$ & $\begin{array}{c}3.7 \\
(0.31 \pm 0.57)\end{array}$ & $\begin{array}{c}11.3 \\
(0.94 \pm 1.54) \\
\end{array}$ \\
\hline \multicolumn{6}{|l|}{ Notommatidae } \\
\hline \multirow[t]{2}{*}{ Cephalodella sp. } & $2009-10$ & $\begin{array}{c}3.0 \\
(0.25 \pm 0.83) \\
\end{array}$ & - & - & - \\
\hline & $2010-11$ & $\begin{array}{c}2.5 \\
(0.21 \pm 0.56)\end{array}$ & - & - & - \\
\hline \multirow[t]{2}{*}{$\begin{array}{l}\text { Total Population } \\
\text { Density (ind. } .^{-1} \text { ) }\end{array}$} & $2009-10$ & 72.9 & 582.3 & 592.5 & 144.2 \\
\hline & $2010-11$ & 76.3 & 249.4 & 153.6 & 57.3 \\
\hline
\end{tabular}

- $\quad$ Depicted absent 
Table 2:- Diversity Indices of rotifer abundance of river Basantar at all the stations.

\begin{tabular}{|l|c|c|c|c|c|c|c|c|}
\hline \multirow{2}{*}{ Diversity Indices } & \multicolumn{4}{|c|}{ Year 2009-10 } & \multicolumn{4}{c|}{ Year 2010-11 } \\
\cline { 2 - 9 } & St I & St II & St III & St IV & St I & St II & St III & St IV \\
\hline Shannon Index & 1.788 & 1.328 & 1.375 & 1.616 & 1.718 & 1.549 & 1.961 & 1.993 \\
\hline Simpson's Index & 0.204 & 0.320 & 0.349 & 0.255 & 0.251 & 0.255 & 0.162 & 0.150 \\
\hline Marglef's Index & 2.098 & 1.571 & 1.723 & 2.012 & 2.308 & 1.631 & 1.986 & 1.976 \\
\hline Pielou's Index & 0.776 & 0.554 & 0.553 & 0.674 & 0.716 & 0.673 & 0.818 & 0.907 \\
\hline
\end{tabular}

Table 3:- Similarity indices to compare the community structure of the rotifer fauna among different stations of river Basantar.

\begin{tabular}{|l|c|c|c|c|}
\hline \multirow{2}{*}{ Stations } & \multicolumn{2}{|c|}{ Year 2009-10 } & \multicolumn{2}{c|}{ Year 2010-11 } \\
\cline { 2 - 5 } & $\begin{array}{c}\text { Sorenson's } \\
\text { Quotient }\end{array}$ & $\begin{array}{c}\text { Morisita-Horn } \\
\text { Index }\end{array}$ & $\begin{array}{c}\text { Sorenson's } \\
\text { Quotient }\end{array}$ & $\begin{array}{c}\text { Morisita- } \\
\text { Horn Index }\end{array}$ \\
\hline St I vs. St II & $66.67 \%$ & 0.536 & $76.19 \%$ & 0.193 \\
\hline St I vs. St III & $63.64 \%$ & 0.681 & $72.73 \%$ & 0.307 \\
\hline St I vs. St IV & $76.19 \%$ & 0.857 & $80 \%$ & 0.828 \\
\hline St II vs. St III & $86.96 \%$ & 0.904 & $95.24 \%$ & 0.857 \\
\hline St II vs. St IV & $72.73 \%$ & 0.834 & $84.21 \%$ & 0.549 \\
\hline St III vs. St IV & $78.26 \%$ & 0.940 & $80 \%$ & 0.729 \\
\hline
\end{tabular}

\section{Conclusion:-}

Rotifer fauna play a significant role in the assessment of ecological status of an aquatic system and thus considered as an important tool for bio-monitoring. From the above discussion, it is concluded that the discharge of industrial waste in to the river Basantar has severely affected the composition and distribution of rotifer fauna inhabiting the river. The higher density of pollution tolerant taxa and disappearance of sensitive taxa at the discharge zone of the river exhibited a clear picture regarding the deteriorating ecological condition of the river. Thus, the present study shall be utilized to frame important guidelines for the implementation of proper conservatory strategies so as to restore the ecological condition of the river.

\section{References:-}

1. A.P.H.A. (1985): Standard Methods for the examination of waste and waste water. $16^{\text {th }}$ edition, American Public Health Association, Washington, D. C.

2. Adoni, A.D. (1985): Workbook on Limnology. Pratibha Publishers, C-10 Gour Nagar, Sagar, India.

3. Ahmad, U., Parveen, S., Khan, A.A., Kabir, H.A., Mola, H.R.A. and Ganai, A.H. (2011): Zooplankton population in relation to physicochemical factors of a sewage fed Pond of Aligarh (UP), India. Biology and Medicine, 3: 336-341.

4. Angeli, N. (1976): Influence de la pollution sur les elements du plankton. pp. 97-133. In: Pesson P (ed) La Pollution Oles Eaux Continentales, Gauthier-Villards, Paris, pp. 285. ISBN 10: 2040101276.

5. Annalakshmi, G. and Amsath, A. (2012): Studies on the hydrobiology of river Cauvery and its tributaries arasalar from Kumbakonam region (Tamil Nadu, India) with reference to phytoplankton. International Journal of Plant, Animal and Environmental Sciences. 2(2): 37-46.

6. Arora, H.C. (1965). Studies on Indian Rotifera- Part VI. On a collection of Rotifera from Nagpur, India, with four new species and a new variety. Hydrobiologia, 26: 444-456.

7. Arora, H.C. (1966): Responses of rotifers to variations in some ecological factors. Proc. Ind. Acad. Sci., 63: 5766.

8. Baker, R.L. (1979): Specific status of Keretella cochearis (Goose) and K. Earliner, Ahlstrom (Rotifera: Branchionidae). Morphological and ecological considerations. Con. J. Zool., 57(9): 1719-1722.

9. Battish, S.K. (1992): Freshwater zooplankton of India. Oxford and IBM Publishing Co. Pvt. Ltd., New Delhi, Bombay, Calcutta.

10. Bekleyen, A. (2003): A taxonomical study on the zooplankton of Goksu Dam Lake (Diyarbakir). Turk. J. Zool., 27: 95-100.

11. Bellos, D., Sawidis, T. and Tsekos, I. (2004): Nutrient chemistry of River Pinios (Thessalia, Greece). Environ. Int., 30: 105-115.

12. Bhagat, V.B., Meshram, C.B., Bobdey, A.D. and Sawane, A.P. (2010): Diversiy of microfauna in Ambadi irrigation dam, of District Akola (Maharashtra). Biosci. Biotech. Res. Comm., 3(1): 104-106. 
13. Chételat, J. and Pick, F.R. (2006): Potamoplankton size structure and taxonomic composition: influence of river size and nutrient concentrations. Limnolgy and Oceanogaphy, 51: 681-689.

14. Dale, V.H., Crisafulli, C.M. and Swanson, F.J. (2005): 25 years of ecological change at Mount St. Helens. Science, 308: 961-962.

15. Devetter, M. and Sed'a, J. (2003): Rotifer fecundity in relation to components of microvial food web in a eutrophic reservoir. Hydrobiologia, 504: 167-175.

16. Dhembare, A.J., (2011). Diversity Indices of Rotifer from Dynaneshwar Water Rahuri, Ahmednagar, Maharashtra. European Journal of Experimental Biology, 1(3): 139- 144.

17. Dirican, S., Haldun, M. and Suleyman, C. (2009): Some physico-chemical characteristics and Rotifers of Camligoze Dam lake, Susehri, Sivas, Turkey. Journal of Animal and Veterinary Advances, 8(4): 715-719.

18. Dumont, H.J. (1983): Biogeography of rotifers. Hydrobiologia, 104: 19-30.

19. Edmondson, W. T. (1992): Freshwater Biology. $2^{\text {nd }}$ edition, International Books and Periodicals Supply Service.

20. Edmondson, W.T. (1965): Reproductive rate of planktonic rotifers as related to food and temperature. Ecol. Manoir, 35: 61-111.

21. Ekhande, A.P., Patil, J.V., Patil, R.D. and Padate, G.S. (2013): Water quality monitoring- Study of seasonal variation of rotifer and their correlation with physicochemical parameters of Yashwant Lake, Toranmal (M.S.) India. Archives of Applied Science Research, 5 (1): 177-181.

22. Eloranta, P. (1980): Zooplankton in a water course polluted by a sulphite pulp mill. Ann. Zool. Fenn., 17(9): 261-267.

23. Ferdous, Z. and Muktadir, A.K.M. (2009): A Review: Potentiality of zooplankton as Bioindicator. American Journal of Applied Sciences, 6(10): 1815-1819.

24. Gannon, J.E. and Stemberger, R.S. (1978). Zooplankton especially crustaceans and rotifers as indicators of water quality. Trans. Am. Micros. Soc., 97: 16-35.

25. Geng, H., Xie, P., Deng, D. and Zhou, Q. (2005). The rotifer assemblage in a shallow, eutrophic Chinese lake and its relationships with Cyanobacterial blooms and Crustacean zooplankton. Journal of Freshwater Ecology, 20(1): 93-100.

26. George, M.G. (1966): Comparative plankton ecology of five fish ponds in Delhi, India, Hydrobiologia, 27: 81108.

27. Gerritsen, J., Carlson, R.E., Dycus, D.L., Faulkner, C., Gibson, G.R., Harcum, J. and Marcowitz, S.A. (1998): Lake and Reservoir Bioassessment and Biocriteria, Technical Guidance Document, US Environmental Protection Agency.

28. Grimm, A.M., Barros, V. and Doyle, M.E. (2000): Climate variability in southern South America associated with El Nino and La Nina events. J. Climate, 13: 35-58.

29. Hendrik, S. (2007): Freshwater animal diversity assessment. Global diversity of rotifers (Rotifera) in freshwater. Hydrobiologia, 595: 245-256.

30. Herzig, A. (1987): The analysis of planktonic rotifer populations: A plea for long term investigations. Hydrobiologia, 147: 163-180.

31. Hulyal, S.B., and Kaliwal, B.B. (2008): Water quality assessment of Almatti Reservoir of Bijapur (Karnataka State, India) with special reference to zooplankton. Environmental Monitoring and Assessment, 139: $299-306$.

32. Javed, A. (1999): Studies on metal eco-toxicity of river Ravi stretch from Shahdera to Head Baloki. Pakistan Journal of Biological Sciences, 2(3): 1062-1068.

33. Javed, M. (2006): Studies on metal contamination levels in plankton and their role as biological indicator of water pollution in the river Ravi. Pakistan Journal of Biological Sciences, 9(2): 313-317.

34. Jyoti, M.K. and Sehgal, H. (1980): Rotifer fauna of Jammu (J\&K), India, Part I. Loricates. Limnologica (Berlin), 129(1): 121-126.

35. Karr, J.R., Fausch, K.D., Angermeyer, P.L, Yant, P.R. and Schlosser, I.J. (1986): Assessment of biological integrity in running waters: a method and its rationale. Illinois Natural Survey Special Publication No. 5.

36. Khalifa, N.S. and Sabae, S.Z. (2012): Investigation on mutual relations between bacteria and zooplankton in Dameitta branch, River Nile, Egypt. Journal of Applied Sciences Research, 8(5): 2679-2688.

37. Kolhe, B.G., Zambare, S.P., Andhale, S.B. and Rane, M.S. (2013): An estimation of plankton population of Godavari River with reference to pollution. Bioscience Discovery, 4(1): 117-120.

38. Kulshreshtra, S.K. and Joshi, M. (1999). Periphyton community of lower lake of Bhopal in relation to sewage pollution. In: Gapal B and Asthana V (ed) Aquatic Science in India Indian Asso. Limno. And Oceano.

39. Landres, P.B., Verner, J. and Thomas, J.W. (1988): Critique of vertebrate indicator species. Conservation Biology, 2: 316-328. 
40. Mageed, A. (2008): Distribution and longterm historical changes of zooplankton assemblages in Lake Manzala (south Mediterranean Sea, Egypt). Egyptian Journal of Aquatic Research, 33(1): 183-192.

41. Majagi, S., and Vijaykumar, K. (2009): Ecology and abundance of zooplankton in Karanja reservoir. Environmental Monitoring and Assessment, 152: 451-458.

42. Margalef, R. (1983): Limnologia. Omega, Barcelona, pp. 1014.

43. Marglef, R. (1968): Perspectives in ecological theory. University of Chicago Press, Chicago, II.

44. Meshram, C.B. (2012): Population dynamics of rotifer in upper Wardha project, District-Amravati (M.S). Asian Journal of Biology and Biotechnology, 1(1)e110: 1-5.

45. Meybeck, M., Kimstach, V. and Helmer, R. (1992): Strategies for water quality assessments. In: Chapman D (ed) Water Quality Assessments. Chapman \& Hall, London.

46. Mishra, S.R. and Saksena, D.N. (1998): Rotifers and their seasonal variation in a sewage collecting Morar (Kalpi) river, Gwalior, India. Journal of Environmental Biology, 19(4): 363-374.

47. Mola, H.R. (2011): Seasonal and spatial distribution of Brachionus (Pallas, 1966; Eurotatoria: Monogonanta: Brachionidae), a bioindicator of eutrophication in lake El-Manzalah, Egypt. Biol. Medi., 3: 60-69.

48. Ogbeibu, A.E. and Edutie L.O. (2002): Effects of brewery effluents on water quality and Rotifers of Ikpoba river, Southern Nigeria. Afr. J. Pollut. Hlth., 1: 1-12.

49. Orcutt, J.D. and Pace, M.L. (1984): Seasonal dynamics of rotifer and crustacean zooplankton populations in a eutrophic, monomictic lake with a note on rotifer sampling techniques. Hydrobiologia, 119: 73-80.

50. Palharya, J.P. and Malviaya, S. (1988): Pollution of the Narmada river at Hoshangabad in Madhya Pradesh and Suggested Measures for Control. In: Trivedy RK (ed) Ecology and Pollution of Indian river. Ashish Publishing House, New Delhi, India, pp. 54-85.

51. Pawar, S.K. and Pulle, J.S. (2005): Qualitative and quantitative study of zooplankton in Pethwadaj Dam, Nanded, Maharashtra, India. J. Aqua Biol., 20: 53-57.

52. Pennak, R.W. (1989): Invertebrates of the United States, Protozoa to Mollusca. $3^{\text {rd }}$ edition.

53. Pielou, E.C. (1969): An introduction to mathematical ecology. John Wiley, New York.

54. Prabhavathy, G. and Sreenivasan, A. (1977): Ecology of warm freshwater zooplankton of Tamil Nadu. Proc. Sym. Warm Water Zoop. Goa Spl. Publication: 319-329.

55. Purushothama, R., Sayeswara, H.A., Goudar, M.A., Harishkumar, K. (2011): Physicochemical profile and zooplankton community composition in Brahmana Kalasi Tank, Sagar, Karnataka, India. Ecoscan., 5(3): 99103.

56. Schleiger, S.L. (2000): Use of an index of Biotic Integrity to detect effects of land uses on stream fish communities in West-central Georgia. Transactions of the American Fisheries Society, 129: 1118-1133.

57. Shannon, C.E. and Weaver W. (1949): The mathematical theory of communication. University of Illinois Press, Urbana, II.

58. Sharma, S., Siddique, A., Singh, K., Chouhan, M., Vyas, A., Solnki, C.M., Sharma, D., Nair, S. and Sengupta, T. (2010): Population dynamics and seasonal abundance of zooplankton community in Narmada river (India). Researcher, 2(9): 1-9.

59. Sharma, S., Solanki, C.M., Sharma, D. and Pir, Z. (2013). Distribution and diversity of Zooplanktons in Madhya Pradesh, India. International Journal of Advanced Research , 1(1): 16-21.

60. Shinde, S.E., Kantikar, V.N., Muley, S.P. and Nimbalkar, R.K. (2011): Studies on the physico-chemical parameters of water and zooplankton diversity in Khan river, Aurangabad district (MS) India. Bioscience Discovery, 02(2): 207-213.

61. Sladecek, V. (1983): Rotifers as indicators of water quality, Hydrobiologia, 100: 169-201.

62. Sorensen, T. (1948): A method of establishing groups of equal amplitude in plant sociology based on similarity of species content and its application to analyses of the vegetation on Danish commons. Kongelige Danske Videnskabernes Selskab Biologiske Skrifter, 5: 1-34.

63. Spoljar, M., Tomljanovic, T., Lalic, I. (2011): Eutrophication impact on zooplankton community: a shallow lake approach. Holist. Approach Environ., 1 (4): 131-142.

64. Stemberger, R.A. (1979): Guide to the Rotifers of the Lauretian Great Lakes. In: Aydin Örstan (ed) An Introduction to Bdelloid Rotifers. USEPA-600/4-79-021, US Environment and Protection Agency, Washington, D.C., 1999. member.aol.com/bdelloid1/deloid.htm

65. Stoddard, J.L., Larsen, D.P., Hawkins, C.P., Johnson, R.K. and Norris, R.H. (2006): Setting expectations for the ecological condition of streams: The concept of reference condition. Ecological Application, 16: 1267-1276.

66. Stone, J.E. and Pence, D.B. (1978): Ecology of helminth parasitism in the bobcat from West Texas. Journal of Parasitology, 64: 295-302. 
67. Sulehria, A.Q.K. and Malik, M.A. (2012). Population Dynamics of Planktonic Rotifers in Balloki Headworks. Pakistan J. Zool., 44(3): 663-669.

68. Suresh, B., Manjappa, S. and Puttaiah, E.T. (2009): The contents of zooplankton of the Tungabhadra river, near Harihar, Karnataka and the saprobiological analysis of water quality. Journal of Ecology and the Natural Environment, 1(9): 196-200.

69. Unni, K.S. (1996): Ecology of River Narmada. APHA publishing Co-operation, 5 Ansari Road, Daryaganj New Delhi, pp. 371.

70. Venkateswarlu, T. and Jayanti, T.V. (1968): Hydrobiological studies of river Sabarmati to evaluate water quality. Hydrobiologia, 31: 442-448.

71. Verma, H. , Devendra, N., Pandey and Shukla, S.K. (2013): Monthly variations of zooplankton in a freshwater body, Futera anthropogenic pond of Damoh District (M.P.). International Journal of Innovative Research in Science, Engineering and Technology. 2(9): 4781-4788.

72. Walting, K., Bottom, G., Pembroke, A. and Maurer, D. (1979): Seasonal variations in Delaware Bay phytoplankton community structure. Mar. Biol., 53: 207-215.

73. Ward, H.B. and Whipple, G.C. (1959): Freshwater Biology IIED. John Wiley and Sons. Inc., New York.

74. Wetzel, R.G. (2001): Limnology: Lake and River Ecosystems. In: A Harcourt Science and Technology Company, $3^{\text {rd }}$ edition, Academic Press, 525B Street, Suite 1900, San Diego, California, pp. 1000

75. Wolda, H. (1983): Spatial and temporal variations in abundance of tropical animals. In: Whitmore, T.C., Chadwick, A.C. and Sutton S.L. (eds) The tropical rainforest: Ecology and Management. Blackwell Scientific Publications, Oxford, U.K., pp. 93-105. 